ogy and what other fields? What are the distinctive problems of this field of library specialization?

As you can see, I have concentrated on education/psychology librarianship in higher education and research institutions. I have assumed that our section is not in business to deal with school librarianship since AASL serves that purpose. Nor is our section primarily concerned with education for librarianship since LED exists for that. Learning resource center librarianship in two-year colleges is somewhat closer to the emphasis of our section; however, the Community and Junior College Section of ACRL and the Audiovisual Section of ISAD adequately cover this interest. I must hasten to add, however, that, although I particularly want to hear from librarians specializing in education/curriculum materials or psychology/ psychiatry in higher education or research institutions, I will be pleased to get responses from other librarians as well. Two groups able to make especially valuable contributions to the discussion are ex-education/psychology librarians now in other career lines, and social science librarians who include education or psychology among their areas of responsibility.

What do I intend to do with the letters once you have written to me? First, I expect to learn something as chairperson about the concerns of my colleagues. Also, I hope in this way to learn of those members of the section who would like to be more actively involved. Perhaps, depending on the kinds and number of responses, letters could be xeroxed and distributed to all correspondents or to circles of people with interests in common, or round robins might be formed.

Finally, your letters will provide topics of grass roots interest for the Annual Conference in Chicago. On Sunday afternoon we are planning to try out discussion circles of members interested in education and behavioral science librarianship. Maybe we should call them "juntos" in memory of one of the founding fathers of American libraries, Benjamin Franklin, and to introduce a bicentennial note. We are likely to ask some of you to co-lead small discussion groups on areas of interest to you, or act as recorders and reporters.

Like most of you nowadays, I am overburdened with work both in my job and in other professional commitments. Nevertheless, I hope you will make the burden even more overwhelming by responding to this, an effort to make a tour of duty as chairperson of your section interactive.

Wayne Gossage, Library Director Bank Street College of Education 610 W. 112 St.

New York, NY 10025

\section{ADDITIONAL ACRL NOMINEES FOR OFFICES, 1976/77}

\section{ASIAN AND AFRICAN SECTION}

Vice-Chairman/Chairman-Elect

Robert Edmund Booth, Director, Wayne State University Division of Library Science, Detroit, MI 48202

John A. Eilts, Near Eastern Bibliographer, University of Michigan Library, Ann Arbor, MI 48104

\section{Secretary}

Mohammed M. Aman, Chairman, Department of Library Science, St. John's University, Jamaica, NY 11432

Josephine R. Fang, Professor, School of Library Science, Simmons College, Boston, MA 02115

\section{Member-at-Large}

Rosalie C. Amer, Technical Services Librarian, Cosumnes River College Library, Sacramento, CA 95823

David G. Donovan, Assistant Director for Administration, University of Notre Dame Memorial Library, Notre Dame, IN 46556

\section{COMMUNITY AND JUNIOR COLLEGE LIBRARIES SECTION}

\section{Vice-Chairman/Chairman-Elect}

J. Daniel Vann III, Chief Librarian and Professor, Staten Island Community College, 715 Ocean Terrace, Staten Island, NY 10301

News items for inclusion in C\&RL News should be sent to Mary Frances Collins, Assistant Director of Libraries for Technical Services, University Library ULB-35A, State University of New York at Albany. 1400 Washington Ave. Albany, NY 12222. Advertising (including classified ads) should be sent to Leona Swiech. Advertising Office American Library Association, 50 E. Huron St. Chicago, IL 60611 . Production and circulation matters are handled by ALA Central Production Unit, at the above address.

News editor: Mary Frances Collins, Assistant Director of Libraries for Technical Services. State University of New York at Albany, Albany. Associate News editor: Anne Dowling, Assistant Libbrarian Acquisitions Department. Library. State University of New York at Albany. Editor: Richard D. Johnson, Milne Library, State University College, Oneonta, New York 13820. President, ACRL: Louise Giles. Executive Secretary, ACRL: Beverly P. Lynch.

College Research Libraries is published by the Association of College and Research Libraries, a division of the American Library Association, 17 times yearly 6 bimonthly journal issues and II monthly (combining July-August) News issues-at 1201-05 Bluff St. Fulton, MO 6525I. Subscription, $\$ 15.00$ a year, or to members of the division, $\$ 7.50$. included in dues. Second-class postage paid at Fulton, Missouri 6525I.

(c) American Library Association 1976. All material in this journal subject to copyright by the Ameriean Library Association may be photocopied for the noncommercial purpose of scientific or educational advancement. 